\title{
Trends in Taxes, Fees and Royalties Paid by the BC Forest Industry 1971-1979
}

by

William A. White ${ }^{1}$

\begin{abstract}
The article combines the findings of Howard (1978) and White (1982) to review the revenues received by the British Columbia and Canadian governments from the BC forest industry between 1971 and 1979 inclusive. Revenues, particularly from timber sale stumpage are shown to fluctuate according to market conditions. General economic performance in the US, as measured by GNP, and the US housing and construction industries also impact significantly on the revenues received from $B C$ forest industry.
\end{abstract}

\section{Résumé}

Cet article combine les résultats obtenus par Howard (1978) et White (1982) afin d'examiner des revenus collectés par le gouvernement fédéral et le gouvernement provincial de l'industrie forestière de la Colombie-britannique durant les années 1971 a 1979. II est montré que des revenus (surtout ceux qui ont été obtenus par le vente de bois sur pied) ont fluctués en réponse aux conditions du marché. La performance de l'économie américaine mesurée par le produit national brut et les industries de logement et de construction ont une influence importante sur les revenus obtenus de l'industrie forestière de la C.-B.

\section{Introduction}

As far back as records exist, aggregate economic activity as measured by GNP has had one dominant characteristic - change. These changes or fluctuations are caused by expansions or recessions occurring simultaneously in a number of economic activities and make up what are commonly known as business cycles.

One of the economic activities which fluctuates and helps to create business cycles is building. Fluctuations in building activity are known as building cycles and these tend to parallel general business cycles (Zivnuska 1952).

These cycles also affect corporate revenues and profits. In particular, the building cycle affects the demand for wood products as well as the revenues and profits of firms engaged in this activity. As corporate revenues and profits change, so also do government receipts. (See Vogel and Trost 1979; Vogel 1975; Legler and Shapiro 1968.) White (1982) and Howard (1978) showed that taxes, fees and royalties paid by the BC forest industry between 1971 and 1979 fluctuated with general business activity.

The object of this paper is to investigate trends in taxes, fees and royalties paid by the $\mathrm{BC}$ forest industry between 1971 and 1979 and relate them to economic performance in North America over the same period.

The period covered by this paper contains portions of two business and building cycles and includes a period of increasing demand (based on value of shipments) for wood products (1971-1972), a peak year (1973), a period of declining

\footnotetext{
1The author is an economist at the Pacific Forest Research Centre of the
} Canadian Forestry Service in Victoria. BC markets (1974), poor markets and a strike (1975) and another period of improving markets including the record setting year of 1979. The study period also saw inflation running at between 5 and 11 percent per annum throughout. Therefore, real dollar values based on the Consumer Price Index are used in this report to eliminate inflation induced distortions in the revenues reported.

The first section of the paper examines trends in taxes, fees and royalties paid to the provincial and federal governments. Revenues to each level of government are compared to determine if certain sources of revenue became more important than others over the study period. The next section of the study presents some simple correlations of revenues with certain economic indicators by which business and building cycles can be measured such as GNP and housing starts. Multiple regressions are used to specify equations which best describe the relationship between these economic indicators and revenues collected. Elasticities are calculated as a measure of the responsiveness of government receipts from the forest industry to fluctuations in economic activity.

The paper will be useful to the public sector as it indicates the impact of market changes on revenues collected from the forest sector and displays the dependence of the BC forest industry on the United States economy.

\section{Provincial Taxes, Fees and Royalties}

In Table 1 tax revenues paid by the forest industry between 1971 and 1979 are shown.

Provincial taxes can be divided into two categories - major and minor. The major taxes include corporate and logging income tax and the social services (sales) tax. Corporate 
Table 1. Estimates ${ }^{1}$ of provincial taxes paid by the BC forest industry 1971-1979.

\begin{tabular}{|c|c|c|c|c|c|c|c|c|c|}
\hline Tax & 1971 & 1972 & 1973 & 1974 & 1975 & 1976 & 1977 & 1978 & 1979 \\
\hline & \multicolumn{9}{|c|}{$000000 \$$} \\
\hline Corporate Income Tax & $\begin{array}{l}8.8 \\
(8.8)^{2}\end{array}$ & $\begin{array}{c}16.5 \\
(15.7)\end{array}$ & $\begin{array}{c}38.8 \\
(31.5)\end{array}$ & $\begin{array}{c}22.1 \\
(17.9)\end{array}$ & $\begin{array}{l}11.4 \\
(8.5)\end{array}$ & $\begin{array}{c}35.6 \\
(25.2)\end{array}$ & $\begin{array}{c}40.3 \\
(27.0)\end{array}$ & $\begin{array}{c}70.2 \\
(44.3)\end{array}$ & $\begin{array}{l}116.5 \\
(69.5)\end{array}$ \\
\hline Logging Income Tax ${ }^{3}$ & $\begin{array}{c}10.1 \\
(10.1)\end{array}$ & $\begin{array}{c}16.4 \\
(15.6)\end{array}$ & $\begin{array}{c}22.0 \\
(19.6)\end{array}$ & $\begin{array}{c}39.2 \\
(31.8)\end{array}$ & $\begin{array}{c}27.9 \\
(20.8)\end{array}$ & $\begin{array}{l}13.8 \\
(9.8)\end{array}$ & $\begin{array}{c}42.0 \\
(28.1)\end{array}$ & $\begin{array}{c}54.1 \\
(34.1)\end{array}$ & $\begin{array}{r}44.8 \\
(26.7)\end{array}$ \\
\hline Corporation Capital Tax & - & - & $\begin{array}{c}2.0 \\
(1.8)\end{array}$ & $\begin{array}{c}4.1 \\
(3.3)\end{array}$ & $\begin{array}{c}4.6 \\
(3.4)\end{array}$ & $\begin{array}{c}9.7 \\
(6.9)\end{array}$ & $\begin{array}{l}11.2 \\
(7.5)\end{array}$ & $\begin{array}{l}11.6 \\
(7.3)\end{array}$ & $\begin{array}{l}11.8 \\
(7.0)\end{array}$ \\
\hline Social Services Tax & $\begin{array}{c}16.5 \\
(16.5)\end{array}$ & $\begin{array}{c}18.7 \\
(17.8)\end{array}$ & $\begin{array}{c}22.7 \\
(20.2)\end{array}$ & $\begin{array}{c}26.9 \\
(21.8)\end{array}$ & $\begin{array}{c}30.3 \\
(22.6)\end{array}$ & $\begin{array}{c}43.4 \\
(30.7)\end{array}$ & $\begin{array}{c}51.6 \\
(34.5)\end{array}$ & $\begin{array}{c}47.1 \\
(29.7)\end{array}$ & $\begin{array}{c}44.1 \\
(26.3)\end{array}$ \\
\hline Forest Protection Tax & $\begin{array}{c}1.1 \\
(1.1)\end{array}$ & $\begin{array}{c}1.2 \\
(1.1)\end{array}$ & $\begin{array}{c}1.1 \\
(1.0)\end{array}$ & $\begin{array}{l}1.0 \\
\text { (.8) }\end{array}$ & $\begin{array}{l}1.1 \\
(.8)\end{array}$ & $\begin{array}{c}1.4 \\
(1.0)\end{array}$ & $\begin{array}{l}1.2 \\
(.8)\end{array}$ & $\begin{array}{l}1.0 \\
\text { (.6) }\end{array}$ & $\begin{array}{c}1 \\
\text { (.1) }\end{array}$ \\
\hline Fuel Tax & $\begin{array}{c}9.2 \\
(9.2)\end{array}$ & $\begin{array}{l}8.5 \\
(8.1)\end{array}$ & $\begin{array}{c}8.9 \\
(7.9)\end{array}$ & $\begin{array}{c}9.4 \\
(7.6)\end{array}$ & $\begin{array}{c}7.0 \\
(5.2)\end{array}$ & $\begin{array}{c}8.6 \\
(6.1)\end{array}$ & $\begin{array}{c}8.3 \\
(5.6)\end{array}$ & $\begin{array}{c}8.9 \\
(5.6)\end{array}$ & $\begin{array}{c}9.3 \\
(5.5)\end{array}$ \\
\hline Land Taxes & $\begin{array}{l}5.9 \\
(5.9)\end{array}$ & $\begin{array}{c}5.3 \\
(5.1)\end{array}$ & $\begin{array}{c}5.1 \\
(4.5)\end{array}$ & $\begin{array}{r}6.8 \\
(5.5)\end{array}$ & $\begin{array}{c}6.8 \\
(5.1)\end{array}$ & $\begin{array}{l}6.6 \\
(4.7)\end{array}$ & $\begin{array}{r}6.5 \\
(4.3) \\
\end{array}$ & $\begin{array}{c}3.2 \\
(2.0)\end{array}$ & $\begin{array}{c}3.7 \\
(2.2)\end{array}$ \\
\hline
\end{tabular}

Source: Howard 1978. White 1982

'See Howard (1978) for details on the estimation of each tax.

2 Numbers in parentheses are in constant 1971 dollars.

${ }^{3}$ Since January 1,1978 the logging tax has been completely offset by credits against federal and provincial taxes. This means that no tax is actually paid by the forest industry but revenue accrues to the B.C. government. Table 1 shows gross logging tax charged

Table 2. Estimates of fees and royalties paid by the BC forest industry 1971-1979.

\begin{tabular}{|c|c|c|c|c|c|c|c|c|c|}
\hline Fees and royalties & 1971 & 1972 & 1973 & 1974 & 1975 & 1976 & 1977 & 1978 & 1979 \\
\hline & \multicolumn{9}{|c|}{$000000 \$$} \\
\hline Tenure fees and rentals & $\begin{array}{l}2.1 \\
(2.1)^{\prime}\end{array}$ & $\begin{array}{c}2.0 \\
(1.9)\end{array}$ & $\begin{array}{l}2.0 \\
(1.8)\end{array}$ & $\begin{array}{c}2.1 \\
(1.7)\end{array}$ & $\begin{array}{c}1.9 \\
(1.4)\end{array}$ & $\begin{array}{c}1.9 \\
(1.3)\end{array}$ & $\begin{array}{l}2.0 \\
(1.3)\end{array}$ & $\begin{array}{c}1.9 \\
(1.2)\end{array}$ & $\begin{array}{l}15.6 \\
(9.3)\end{array}$ \\
\hline Timber sale stumpage & $\begin{array}{c}49.7 \\
(49.7)\end{array}$ & $\begin{array}{c}91.2 \\
(87.0)\end{array}$ & $\begin{array}{c}230.6 \\
(205.3)\end{array}$ & $\begin{array}{c}181.6 \\
(147.4)\end{array}$ & $\begin{array}{c}43.4 \\
(32.4)\end{array}$ & $\begin{array}{c}43.7 \\
(30.1)\end{array}$ & $\begin{array}{c}62.3 \\
(41.7)\end{array}$ & $\begin{array}{c}159.9 \\
(100.1)\end{array}$ & $\begin{array}{c}416.9 \\
(248.7)\end{array}$ \\
\hline Timber royalties & $\begin{array}{c}5.6 \\
(5.6)\end{array}$ & $\begin{array}{c}5.3 \\
(5.1)\end{array}$ & $\begin{array}{c}6.9 \\
(6.1)\end{array}$ & $\begin{array}{c}7.5 \\
(6.1)\end{array}$ & $\begin{array}{c}6.1 \\
(4.6)\end{array}$ & $\begin{array}{c}6.7 \\
(4.7)\end{array}$ & $\begin{array}{c}8.6 \\
(5.8)\end{array}$ & $\begin{array}{c}7.5 \\
(4.7)\end{array}$ & $\begin{array}{l}12.8 \\
(7.6)\end{array}$ \\
\hline Other & $\begin{array}{c}2.4 \\
(2.4)\end{array}$ & $\begin{array}{l}2.9 \\
(2.8)\end{array}$ & $\begin{array}{c}3.8 \\
(3.4)\end{array}$ & $\begin{array}{l}5.0 \\
(4.1)\end{array}$ & $\begin{array}{c}5.3 \\
(4.0)\end{array}$ & $\begin{array}{l}9.3 \\
(6.6)\end{array}$ & $\begin{array}{c}9.4 \\
(6.3)\end{array}$ & $\begin{array}{l}13.6 \\
(8.6)\end{array}$ & $\begin{array}{l}12.4 \\
(7.4)\end{array}$ \\
\hline Total & $\begin{array}{c}59.8 \\
(59.8)\end{array}$ & $\begin{array}{l}101.4 \\
(96.8)\end{array}$ & $\begin{array}{c}243.3 \\
(216.7)\end{array}$ & $\begin{array}{c}196.2 \\
(159.3)\end{array}$ & $\begin{array}{c}56.7 \\
(42.3) \\
\end{array}$ & $\begin{array}{c}61.6 \\
(43.5)\end{array}$ & $\begin{array}{c}82.3 \\
(55.1)\end{array}$ & $\begin{array}{c}182.9 \\
(115.4)\end{array}$ & $\begin{array}{c}457.7 \\
(273.1)\end{array}$ \\
\hline
\end{tabular}

Source: Howard 1978. White 1982

Numbers in parentheses are constant 1971 dollars

income tax and logging income tax appeared to fluctuate with market conditions over the study period. They differed, however, in that receipts from corporate income tax increased or decreased in the same year that the markets were strong or weak, whereas logging income tax receipts in a given year reflected market conditions in the previous year. Also, toward the end of the study period corporate income tax became a more important source of revenue relative to other provincial taxes. This was a result of a decrease in the rate of logging income tax from 15 percent to 10 percent and increases in the rate of provincial corporate tax from 10 percent in 1971 to 15 percent by 1976 . The social services or sales tax received showed a tendency to increase steadily over the period. It deviated from this trend only when the tax rate changed. This is more a reflection of the means of estimation ${ }^{2}$ than a real trend. In reality, the social services tax collected from the forest industry should vary somewhat according to market conditions. The minor taxes (those yielding under $\$ 10$ million 1971 dollars per year) were relatively stable over the study period but showed slight declines in real terms with the exception of the Corporation Capital Tax.

Table 2 presents the fees and royalties paid by the $\mathrm{BC}$ forest industry between 1971 and 1979. Timber sale stumpage is highly responsive to market conditions. When demand for

It was estimated that 15 percent of all taxable purchases by firms were from the forest industry for each year of the study (see Howard (1978)). In reality this figure fluctuates from year to ye $6 \mathrm{r}$. forest products is high increased stumpage revenues result. Tenure fees and rentals, timber royalties and other fees are quite stable relative to timber sale stumpage revenues. This is borne out by Table 3 which presents timber sale stumpage as a percentage of total fees and royalties collected. During peak years such as 1973 and 1979 timber sale stumpage made up more than 90 percent of total fees and royalties paid while in years of poor or recovering markets such as 1975 and 1976 timber sale stumpage was less than 80 percent of total fees and royalties.

\section{Provincial Taxes Versus Fees and Royalties}

It is evident from data presented in Tables 1 and 2 that fees and royalties paid were more volatile than taxes. This can be explained by i) the lag in the collection of logging income tax (see Table 1), ii) the means used to estimate social services tax revenue from the forest industry (noted earlier), iii) the relative stability of revenues from minor taxes, iv) and the sensitivity of timber sale stumpage to market conditions. The only period when fees and royalties were less volatile than tax payments was between 1975 and 1977 when timber sale stumpage was slow to respond to the upswing in demand following the recession. This trend can be explained in part by a lag in collecting fees and royalties and in the start-up of logging activity as inventories are reduced.

Another important trend evident from the data is that taxes became a somewhat more important source of revenue in 
Table 3. Timber sale stumpage as a percentage of total fees and royalties paid by the BC forest industry 1971-1979.

\begin{tabular}{ccccccccc}
1971 & 1972 & 1973 & 1974 & $\begin{array}{c}1975 \\
\text { Percent }\end{array}$ & 1976 & 1977 & 1978 & 1979 \\
83 & 90 & 95 & 93 & 77 & 71 & 76 & 87 & 91 \\
\hline
\end{tabular}

Table 4. Provincial taxes as a percentage of fees and royalties 1971-1979.

\begin{tabular}{ccccccccc}
\hline 1971 & 1972 & 1973 & 1974 & $\begin{array}{c}1975 \\
\text { Percent }\end{array}$ & 1976 & 1977 & 1978 & 1979 \\
86 & 66 & 41 & 56 & 157 & 193 & 196 & 107 & 50 \\
\hline
\end{tabular}

comparison to fees and royalties over the study period (see Table 4). In the three years up to the first peak year (1973) taxes declined from 86 percent of royalties in 1971 to just 41 percent in 1973. Six years later, in the three years up to the second peak in 1979, the corresponding figures were from 196 percent in 1977 to 50 percent in 1979. Increases in real revenues obtained from corporate and logging income taxes and the introduction of the corporation capital tax are the main reasons for the shift. This appears to be an attempt by the $\mathrm{BC}$ government to stabilize receipts from the forest industry. Vogel and Trost (1979) found that states which suffered from fluctuations of economic activity tended to create revenue collecting structures to minimize this variability. $\mathrm{BC}$ also appears to be working towards this stability.

\section{Federal Revenues}

Federal revenues from the $\mathrm{BC}$ forest industry are obtained from the corporate income tax and excise tax. Revenues from these sources fluctuated over the study period with general market demand.

Table 5 shows provincial and federal taxes received from the $\mathrm{BC}$ forest industry.

Both federal and provincial taxes fluctuated with market conditions. Though federal tax revenues did not experience the wide swings seen in provincial fees and royalties, they were less stable than provincial tax revenues. As noted earlier. the stability of provincial tax revenues is influenced by the lag in the collection of the logging income tax and the stability of the minor taxes and the social services tax

Provincial tax revenues from the forest industry have increased relative to federal tax revenues during the study period. This can in part be explained by the increase in the provincial corporate tax rate along with the decrease in the federal tax rate. (This is discussed in more detail in the next section.) As well, a decrease in federal excise tax rates had a greater effect on federal taxes than a similar decrease in the provincial social services tax rate, since the federal excise tax makes up a greater proportion of federal taxes from the forest industry than the social services tax does of provincial taxes from the same industry.

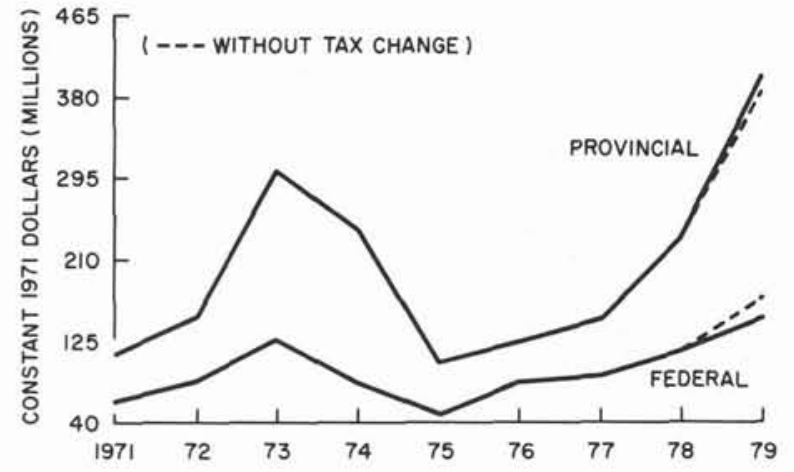

Figure 1. Estimates of taxes, fees and royalties paid by the $B C$ forest industry 1971-1979.

\section{Provincial Revenues Versus Federal Revenues}

By combining provincial taxes, fees and royalties, provincial revenues from the $\mathrm{BC}$ forest industry can be compared to federal revenues from the same source.

It can be seen in Figure 1 and Table 5 that provincial revenues exceeded federal revenues throughout the study period. Although both sets of revenues fluctuate according to market conditions, provincial revenues show a greater degree of variability due primarily to the sensitivity of timber sale stumpage to market conditions. Another recognizable trend is that provincial revenues from the $\mathrm{BC}$ forest industry are rising more rapidly than federal revenues. The impetus for this has been the shifting of corporate tax points to the provinces from the federal government and the decrease in the federal excise tax.

The revenue picture in 1979 would have looked somewhat different if the federal and provincial corporate tax rates had remained at their 1971 levels of 50 and 10 percent respectively and if the federal excise tax had remained at 12 percent. Federal taxation revenues would have exceeded provincial levels by about $\$ 75$ million rather than the estimated $\$ 30$ million shown in Table 5 and in total, provincial revenues would have exceeded federal revenues by only about $\$ 200$ million rather than $\$ 250$ million. Also, the relative rates of increase of provincial and federal revenues from the forest industry would have been more similar (See Figure 1).

\section{The Impact of Business Cycles on Revenues Collected}

In this section the impact of business and building cycles on revenues collected by the provincial and federal governments is studied. This is accomplished by examining the correlation between certain key economic indicators and revenues. Finally, equations which best describe the variability in revenues collected are developed.

\begin{tabular}{|c|c|c|c|c|c|c|c|c|c|}
\hline & 1971 & 1972 & 1973 & 1974 & 1975 & 1976 & 1977 & 1978 & 1979 \\
\hline & \multicolumn{9}{|c|}{$000000 \$$} \\
\hline Federal taxes & $\begin{array}{l}62.6 \\
\left(62.6^{1}\right)\end{array}$ & $\begin{array}{c}84.1 \\
(80.2)\end{array}$ & $\begin{array}{c}148.5 \\
(132.2)\end{array}$ & $\begin{array}{l}102.9 \\
(83.5)\end{array}$ & $\begin{array}{c}63.9 \\
(47.7)\end{array}$ & $\begin{array}{l}124.1 \\
(87.7)\end{array}$ & $\begin{array}{l}139.9 \\
(93.6)\end{array}$ & $\begin{array}{c}195.7 \\
(123.5)\end{array}$ & $\begin{array}{c}279.4 \\
(166.7)\end{array}$ \\
\hline Provincial taxes & $\begin{array}{l}31.6 \\
(51.6)\end{array}$ & $\begin{array}{c}66.6 \\
(63.6)\end{array}$ & $\begin{array}{l}100.6 \\
(89.6)\end{array}$ & $\begin{array}{l}109.5 \\
(88.9)\end{array}$ & $\begin{array}{l}89.1 \\
(66.5)\end{array}$ & $\begin{array}{l}119.1 \\
(89.2)\end{array}$ & $\begin{array}{c}161.1 \\
(107.8)\end{array}$ & $\begin{array}{c}196.1 \\
(123.7)\end{array}$ & $\begin{array}{r}230.3 \\
(137.4)\end{array}$ \\
\hline Fees and royalties & $\begin{array}{c}59.8 \\
(59.8)\end{array}$ & $\begin{array}{l}101.4 \\
(96.8)\end{array}$ & $\begin{array}{l}243.3 \\
(216.7)\end{array}$ & $\begin{array}{c}196.2 \\
(159.3)\end{array}$ & $\begin{array}{c}56.7 \\
(42.3)\end{array}$ & $\begin{array}{c}61.6 \\
(43.5)\end{array}$ & $\begin{array}{c}82.3 \\
(55.1)\end{array}$ & $\begin{array}{c}182.9 \\
(115.4)\end{array}$ & $\begin{array}{c}457.7 \\
(273.1)\end{array}$ \\
\hline Provincial total & $\begin{array}{c}111.4 \\
(111.4)\end{array}$ & $\begin{array}{c}168.0 \\
(160.4)\end{array}$ & $\begin{array}{c}343.9 \\
(306.3)\end{array}$ & $\begin{array}{c}305.7 \\
(248.2)\end{array}$ & $\begin{array}{c}145.8 \\
(108.8)\end{array}$ & $\begin{array}{c}180.7 \\
(127.7)\end{array}$ & $\begin{array}{c}243.4 \\
(162.9)\end{array}$ & $\begin{array}{c}379.0 \\
(239.1)\end{array}$ & $\begin{array}{c}688.0 \\
(410.5)\end{array}$ \\
\hline
\end{tabular}

'Numbers in parentheses are constant 1971 dollars 


\section{Correlations with key indicators}

One would expect to find a very strong correlation between the value of production in the forest products industry and government revenues collected from that industry. Indeed, significant correlation coefficients were obtained for all simple regressions involving value of production (see Table 6 ). The lower value for fees and royalties can be attributed in part to the lags inherent in the timber sale stumpage system. These include a lag in logging as the industry recovers from a recession and a lag in the collection of the fees once they have been assessed.

Figure 2 shows more clearly the relationship between forest industry value of production and revenues collected by the provincial and federal governments. Note that provincial taxes and federal revenue are quite stable (between 1.5 and 3 percent), as a percentage of value of production while fees and royalties vary between 3 and 7 percent. Provincial revenues were greater than federal revenues for all years of the study. In Figure 2 it can be seen that as a percentage of value of production, provincial revenues tend to exceed federal revenues by a greater amount during strong markets and that the revenues are much closer during the soft market period. The variability of this ratio can be attributed to the volatility of timber sale stumpage receipts. The fact that the peaks and low points occur in the year following their occurance in the market is caused by the lags inherent in the timber sale stumpage system.

Table 6 displays the correlation coefficients obtained when key economic indicators are correlated with provincial and federal revenues collected during the same year $(t)$ and the previous year $(t-1)$. The results show that provincial tax revenues were closely correlated with general economic conditions as reflected by real GNP for the US and Canada. Canadian construction expenditures also showed a significant degree of correlation with provincial tax revenues. Fees and royalties collected by the provincial government were significantly correlated with the strength of the US construc-

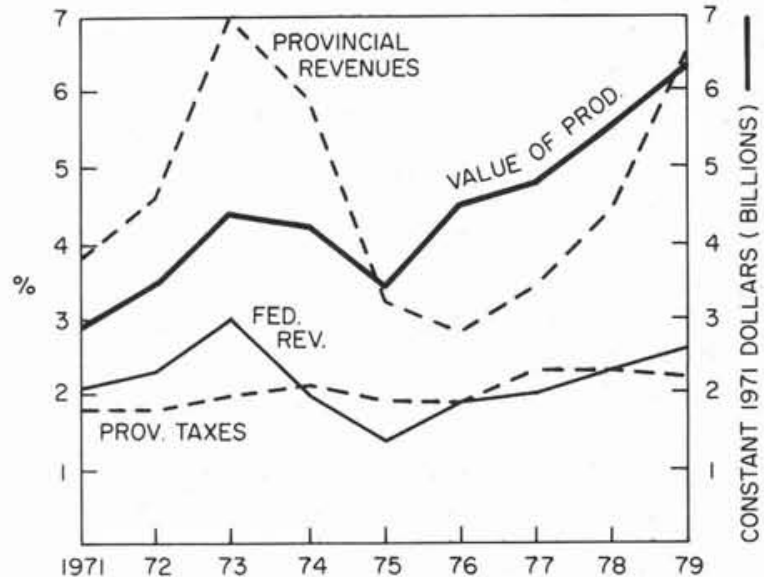

Figure 2. Value of $\mathrm{BC}$ forest products produced and estimates of taxes, fees and royalties as a percentage of value of $\mathrm{BC}$ forest products produced.

tion industry, particularly the residential construction industry. Federal revenues were correlated both with real GNP and the US residential construction industry.

It is evident from the correlation coefficients that revenues from the $\mathrm{BC}$ forest industry tend to fluctuate with the business cycle. Revenues collected are particularly sensitive to cycles in the United States economy with fluctuations in the housing and construction industries being particularly important. This reflects the importance of the United States market where 34 percent (COFI 1980 and Canada 1980) of all manufactured $\mathrm{BC}$ forest products were shipped in 1980 .

By combining variables used earlier in this section, equations can be developed which describe the relationship between revenues collected from the forest industry and certain key economic indicators. Equations (1) and (2) best de-

Table 6. Simple correlations of revenues with key economic indicators.

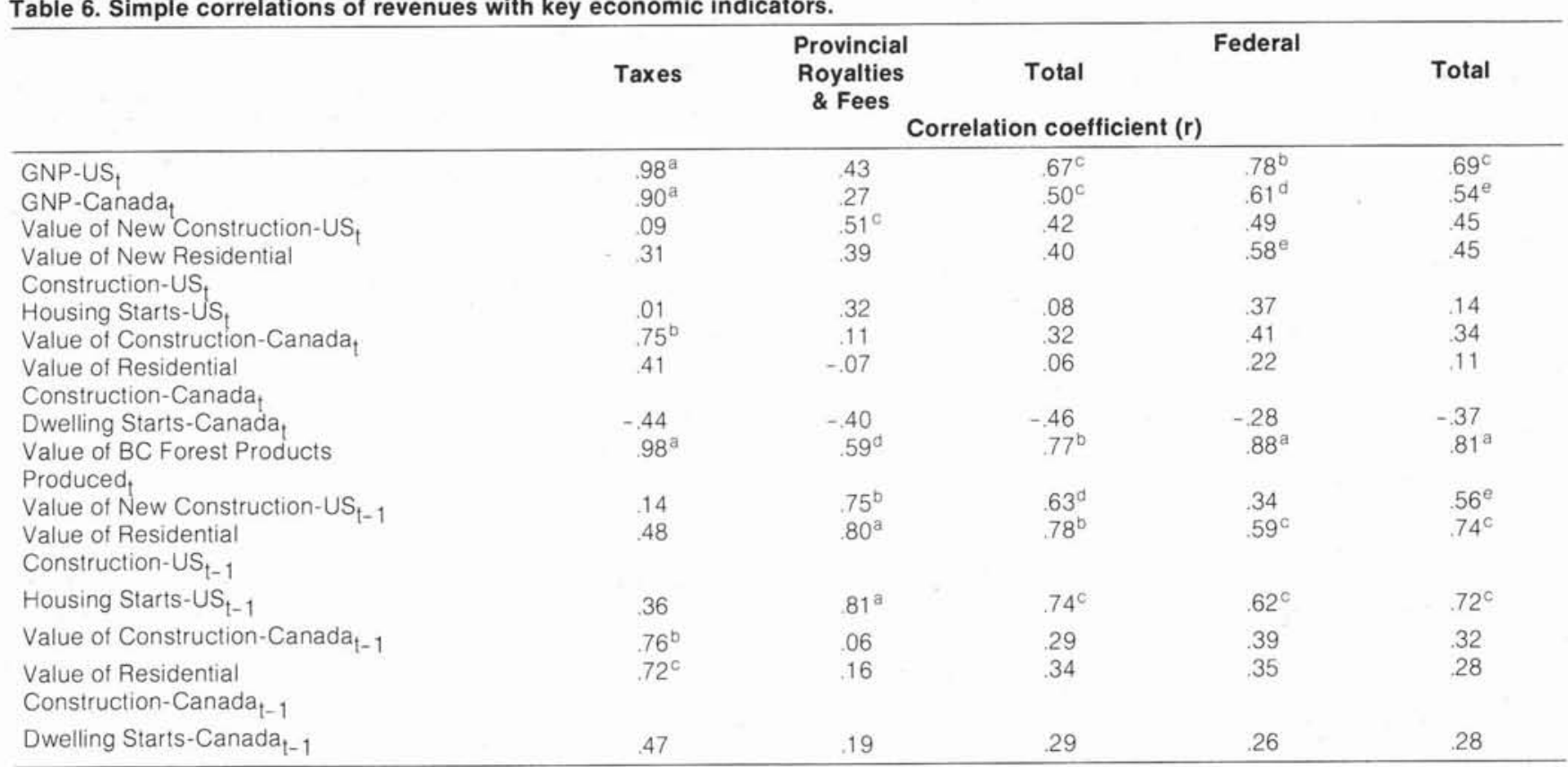

a significant at .005 level b significant at 01 level

c significant at 025 level

d signiticant at .05 level

e signiticant at 10 level 
scribe the pattern of revenue collection between 1971 and 1979

$$
\begin{aligned}
& \text { PREV }_{\mathrm{t}}=-1414.67+.65 \text { UGNP }_{\mathrm{t}}+7.09 \mathrm{UNC}_{\mathrm{t}-1} \\
& \begin{array}{lll}
(-4.99) \quad(4.16) \quad(4.09) & 0
\end{array} \\
& R^{2}=.85 \bar{R}_{2}=.82 \quad F_{(2,6)}=16.4 b \quad D W=2.13 \\
& \text { TREV }_{t}=-1827.24+.94 \text { UGNP }_{t}+8.54 \text { UNC }_{t}
\end{aligned}
$$

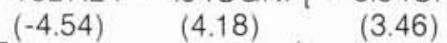$$
R^{2}=.83 \bar{R}_{2}=.80 \quad F(2,6)=14.2 \mathrm{~b} \quad \mathrm{DW}=2.10
$$

Where: PREV $\mathrm{t}_{\mathrm{t}}=$ Provincial revenues from the forest industry

$U_{G N P}=$ United States gross national product

$\mathrm{UNC}_{\mathrm{t}-1}=$ Expenditures on new construction in the US

TREV $_{\mathrm{t}}=$ Provincial and Federal revenues from the forest industry

b Significant at 01 level.

These equations show that both provincial and federal revenue from the $\mathrm{BC}$ forest industry can best be explained by movements in current US GNP and by expenditures on new construction in the US in the previous year. This again shows the importance of the US market to the BC forest industry. It is also interesting to note the minimal importance of the Canadian economy in determining revenues accruing from the forest industry. When variables such as Canadian GNP or construction expenditures were included in the equations that were statistically nonsignificant and the amount of explained variance decreased.

The equations have only minimal use as a forecasting tool because of the constant changes in both provincial and federal revenue structures. Thus, the equations provide only a snapshot of the important relationships between 1971 and 1979. Indeed, ex ante and ex post forecasts tended to significantly underestimate revenues received. So, although the general economic indicators which influence revenues may remain the same, the coefficients attached to them would change.

\section{Elasticities}

Elasticity is a measure of percentage change of an independant variable on the dependant variable. The elasticity of revenues with respect to US GNP and new construction can be defined as the percentage change in revenues divided by the percentage change in US GNP or new construction. By determining the point elasticities of the revenues at the mean value of each of the independant variables, the responsiveness of revenues with respect to these variables can be determined.

Table 7 shows that revenues are quite responsive to changes in US GNP and new construction expenditures. A one percent change in either of these led to a 3 or 4 percent change in revenue collected. The dollar equivalents of these changes are also shown (in parentheses) in the table.

Therefore, it can be stated that a one percent increase in US GNP or new construction expenditure will lead to about an $\$ 8$ million increase in provincial receipts and a \$10-12 million increase in total government receipts from the BC forest industry assuming the tax and fee structure remains unchanged.

Kaish (1982) noted that the Canadian growth cycle is influenced by cycles in the US economy and pointed out that similar results were obtained by Rosenbluth $(1957,1958)$, Chambers (1958) and Hay (1966). It follows that policies affecting the US economy will be felt in Canada. More specifi-
Table 7. Point elasticities ${ }^{1}$ at the means and their dollar impacts (millions of dollars).

\begin{tabular}{lll}
\hline & US GNP & UNC $_{\mathbf{t}-\mathbf{1}}$ \\
\hline $\begin{array}{l}\text { Provincial revenue } \\
\text { Total revenue }\end{array}$ & $3.94(\$ 8.2)$ & $3.82(\$ 8.0)$ \\
\hline & $3.89(\$ 11.96)$ & $3.14(\$ 9.6)$ \\
\hline$E_{i}=B_{i}$ & \\
&
\end{tabular}

cally it is clear from the above analysis that US policies affecting GNP and construction will have an affect on the revenues collected from the forest industry. For example, until recently the US was pursuing a policy of battling inflation at the expense of economic growth. This meant little real GNP growth in the US and consequently low provincial and federal government revenues from the $\mathrm{BC}$ forest industry. A second example of a US policy impacting on revenues from the forest industry is provided by the ill-fated Lugar Bill which was vetoed by President Reagan in June 1982. The Lugar Bill was designed to stimulate the housing industry, and could have resulted in 200000 additional housing starts in the US. This increase in starts would have resulted in an eight percent increase in BC lumber production (Anonymous 1982) and associated increases in government revenues.

\section{Conclusion}

Taxes, fees and royalties paid by the $\mathrm{BC}$ forest industry tend to fluctuate according to market conditions. The fluctuations are particularly apparent in timber sale stumpage revenues and corporate and logging income tax.

Provincial tax revenues are the most stable of the major revenue sources investigated. Their increasing importance as a revenue source should help to stabilize the revenues accruing from the forest industry. This will by no means break the tie that binds revenue from the forest industry to market conditions but should help to smooth out the wide fluctuations noted in this study.

Federal revenues will continue to show similar fluctuations to those experienced in this study as the federal taxation tools remain unchanged and there is no foreseeable change in the cyclical nature of the forest products industry.

Revenues from the forest industry are very responsive to the performance of the industry and to economic conditions in general as measured by US GNP. The US housing and construction industries and US government policies affecting these industries have a significant impact on the revenues collected from the $\mathrm{BC}$ forest industry. This will continue as long as the US remains the primary destination for BC forest products.

\section{References}

Anonymous, 1982. Well aimed rifle shot proves a blank. Madison's Can. Lum. Report 32(25): 1.

Canada, 1980. Canadian Forestry Statistics. Statistics Canada. Catalogue 25-202. Minister of Supply and Services Canada. Ottawa.

Chambers, E.J. 1958. Canadian business cycles since 1919. Can. J. Econ. \& Pol. Sci. 24: 406-410.

COFI 1980. Annual Report. Vancouver

Hay, K.A.J. 1966. Early twentieth century business cycles in Canada. Can. J. Econ. \& Pol. Sci. 32: 354-365.

Howard, W.G. 1978. Estimates of taxes, fees and royalties paid by the BC forest industry and its employees 1971-1975. Can. For. Serv., Pac. For. Res, Cent. Inf. Rep. BC-X-181. 
Kaish, S. 1982. A note on dating the Canadian growth cycle. Can. J. Econ. XV(2): 363-368

Legler, J.B. and P. Shapiro, 1968. The responsiveness of state tax revenue to economic growth. National Tax Journal. 23(1): 4856 .

Rosenbluth, G. 1957. Changes in Canadian sensitivity to United States business fluctuations. Can. J. Econ. \& Pol. Sci. 23. 480-503

1958. Changing structural factors in Canadian sensitivity to United States business fluctuations. Can. J. Econ. \& Pol. Sci. 24: $21-43$

Vogel, R.C. and R.P. Trost, 1979. The response of state government receipts to economic fluctuations and the allocation of counter-cyclical revenue sharing grants. Rev. of Econ. \& Stat. 61(3): $389-400$

Vogel, R.C. 1975. The responsiveness of state and local receipts to changes in economic activity: extending the concept of the full employment budget. Joint Econ. Committee of the US Congress. Studies in Price Stability and Economic Growth. June 1975: 21-35.

White, W.A. 1982. Estimates of taxes, fees and royalties paid by the BC forest industry 1976-79. Can. For. Serv., Pac. For. Res. Cent. Inf. Rep. BC-X-232.

Zivnuska, J.A. 1952. Business cycles, building cycles and commercial forestry. New York Institute of Public Administration.

Programme d'assurance collective de l'IFC

\section{Nous avons amélioré votre régime!}

- Nouveaux taux plus bas

- Assurance accidents

- Assurance vie des personnes à charge

- Indemnité maximale de $250000 \$$

\section{Pour plus de renseignements, veuillez jeter un coup d'oeil à la brochure que vous recevrez en août.}

Nous sommes convaincus que vous serez enchanté de ces nouveaux taux et garanties qui vous sont offerts.

\section{Pour un avenir assuré, compétence personnalisée

